\title{
Achieving Sustainable Competitive Advantage Through Intellectual Capital and Corporate Character: The Mediating Role of Innovation
}

\section{Osiągnięcie trwałej przewagi konkurencyjnej za pomocą kapitału intelektualnego i podejścia korporacyjnego: pośrednicząca rola innowacji}

\author{
Huan Xiao*, Dengke Yu** \\ School of Management, Nanchang University, Nanchang 330031, Jiangxi, China \\ E-mails:*15797901711@163.com,**yudengke@ncu.edu.cn (corresponding author)
}

\begin{abstract}
This study aims to discuss the impacts of intellectual capital and corporate character on sustainable competitive advantage.

The structural equation model is used to analyze the relationships between intellectual capital, corporate character and sustainable competitive advantage, which are mediated by technological innovation and business model innovation, based on a survey of 377 observations in China.

The empirical results indicate that the intellectual capital and corporate character are as the doors that enterprises can open to acquire technological innovation and business model innovation, which are beneficial to achieving and maintaining sustainable competitive advantage. The findings provide some implications for entrepreneurs that their enterprises should focus on the coordination and balance of intellectual capital and corporate character for better achieving the perfect integration of cost leading strategy and differentiation strategy on the basis of mixing technological innovation and business model innovation together. Such strategy helps enterprises to realize sustained growth.

This study provides scholars a new binary perspective to explore the source of sustainable competitive advantage.
\end{abstract}

Key words: sustainable competitive advantage, intellectual capital, corporate character, innovation, structural equation model

\section{Streszczenie}

Niniejszy artykuł ma na celu omówienie wpływu kapitału intelektualnego i podejścia korporacyjnego na trwałą przewagę konkurencyjną.

Przyjęty model równania strukturalnego posłużył do analizy związków między kapitałem intelektualnym, podejściem korporacyjnym i trwałą przewagą konkurencyjną, w czym pośredniczą innowacje technologiczne i innowacje modelu biznesowego. Badania oparto na 377 przykładach z Chinach.

Uzyskane wyniki wskazują, że kapitał intelektualny i podejście korporacyjne są 'drzwiami', które przedsiębiorstwa mogą otworzyć, aby uzyskać innowacje technologiczne i innowacje w modelu biznesowym, korzystne dla osiągnięcia i utrzymania trwałej przewagi konkurencyjnej. Artykuł dostarcza przedsiębiorcom pewnych wskazówek, aby ich przedsiębiorstwa koncentrowały się na koordynacji i równowadze kapitału intelektualnego oraz podejścia korporacyjnego, aby lepiej osiągnąć pełną integrację strategii wiodącej pod względem kosztów i strategii różnicowania na podstawie wprowadzanych innowacji technologicznych i innowacji modelu biznesowego. Taka strategia pomaga przedsiębiorstwom osiągnąc zrównoważony wzrost.

Przeprowadzone badania pokazują uczonym nową perspektywę binarną, pozwalającą odkryć źródło zrównoważonej przewagi konkurencyjnej.

Słowa kluczowe: trwała przewaga konkurencyjna, kapitał intelektualny, podejście korporacyjne, innowacje, model równania strukturalnego 


\section{Introduction}

Competition in the business world is unavoidable, for that, every effort is required to always know and understand what is happening in the market, what customer wants; and trace the changes in the business environment so as to compete with others. Hence, an attempt to understand what resources need and how to manage them should always be created to achieve sustainable competitive advantage.

The so-called competitive advantage refers to the market goal of which a corporation can win higher profit margin or greater market share when it faces similar customer groups with competitors in the market (Ranjith, 2016). Corporate competitive advantage is apparently formed by adapting to the changes of external environment, but in depth, it is supported by internal innovation. It is dependent on the technology and knowledge underlying product quality and production cost, which help preventing competitors from imitating entry (Nilssen et al., 2015). The formulation of corporate strategy based on taking an overall consideration of external environment and internal capabilities is in favour of obtaining competitive advantage. The previous theories stating the sources of competitive advantage has considered both the external environment and internal resources, but a more balanced and integrative construct is also required. In the new economic environment characterized by fierce knowledge-intensive competition, rapidly changing customer need, and open and internet-based marketing channel, the simple application of external environment or internal resources cannot ensure the achievement and sustainability of corporate competitive advantage.

What kind of resources and capabilities should companies rely on, and what kind of strategies and mechanisms could they take to win the sustainable competitive advantage and to promote corporate growth in the new economic era? Academics generally believe that organizations could rely on the management of competitive strategy to treat with the above issues (Teece et al., 2015). According to the theory of competitive strategy, an organization's business strategy consists of three type of solutions, i.e. cost leadership, differentiation and centralization, of which the last one is the specific application of the former two in market segments.

In general, the implementation of cost leading strategy relies on twofold factors: knowledge and high technology, and economies of scale. Taking the limitation of economies of scale into consideration, we can regard this strategy as intellectual-capital-based. Through the creation, absorption, flow, transfer and utilization of intellectual capital, technological innovation can be effectively promoted to control the cost driving factors and reconstruct organization's value chain. This strategy supports organization's core competence and connotative development characterized by technology-driven. However, influenced by the particular market condition of diversified and personalized customer demand, the intellectual-capital-based cost leading strategy is facing challenges, meanwhile the differentiated competitive strategy becomes more important for organizations to achieve temporary competitive advantage. Nevertheless, in terms of the source of differentiation, this strategy requires greater theoretical support in consideration of the existing research.

According to the study of Resnick (2003), an organization could achieve competence through two sources: intellectual capital including knowledge, technology and so on is the source of core competence, and corporate character is the source of differentiated competence. Inspired by this, we are indicated that the differentiated competence or differentiated competitive advantage can be created by the cultivation and optimization of corporate character through developing characteristic technologies, providing differentiated products, delivering personal service, building unique brand image, etc.. The corporate character, similar to but different from the organizational culture, embedded in the organization, system and process, could make one corporation different from its competitors in terms of production and business model. To sum up, organizational growth could be realized on the basis of a new dual innovation system, which balance, coordinate and integrate technological innovation and business model innovation, driven by both the intellectual capital and corporate character together.

In addition to the significant role of intellectual capital and corporate character in the innovation-driven growth, we should also pay great attention to the relationship between them. An ideal ambitious enterprise should take the intellectual capital as latent driver, take the corporate character as explicit supporter, and then achieving its sustainable competitive advantage through continuously accumulating and updating the temporary competitive advantage on the basis of the core competence. This should be the key of organization's sustainable development in the new economic environment.

Therefore, our research from the perspective of the integration of intellectual capital and corporate character would provide an effective way to establish a sustainable competitive strategy. It reveals a comprehensive mechanism for achieving sustainable competitive advantage, through a new dual innovation system driven by intelligence and character. The findings proposed in the paper can help organizations gain sustainable competitive advantage, and enrich the relevant theories about corporate character, dual innovation and competitive advantage.

\section{Research Hypotheses and Framework}

\subsection{Sustainable competitive advantage}

In the market competition, enterprises not only hope to gain temporary competitive advantage in a market 
segment, but also expect to keep and update it in the long run through continuously resisting the erosion of competitors. In general, an enterprise is identified as possessing sustainable competitive advantage when the existed or potential competitors cannot duplicate or they should cost much to imitate its success.

There are lots of different theoretical explanations for enterprises how to gain competitive advantage, especially sustainable competitive advantage. The market structure school, represented by Porter and Millar (1995), adheres to the exogeneity of corporate competitive advantage, with particular emphasis on the decisive role of incomplete market structure. Its essence is to examine the influence of competition forces on corporate decision-making in the industrial environment. However, the empirical study by Lippman and Rumelt (1982) shows that the long-term profit rate in the industry is more widely dispersed than among industries, which indicates that an enterprise's competitive advantage is not from the external market force, but from the internal enterprise itself. This criticizes that the market structure school has focused too much attention on the external environment, overemphasizing the role of market positioning but neglecting the competence of a particular and effective organization. In the long term, it is not conducive to the cultivation of corporate sustainable competitive advantage.

Therefore, the school of resource-based competition emerged. It adheres to the endogeneity of the competitive advantage, and proposes that the heterogeneity of organizational resources and abilities actually supports the sustainable competitive advantage (Baum and Dobbin, 2016). Extending this theory, Prahalad and Hamel (2000), who represent the capability-based competence school, present that the core competence is one of the significant sources of sustainable competitive advantage.

However, similar to the market structure theory, the endogenous growth theories such as resource-based and capability-based competence face limitations to explain the total factors of sustainable competitive advantage. The factors regarding external environment such as industrial structure and market positioning do influence the survival and development of organizations. For example, a survey mentioned in the study of Senge (1992) found that $1 / 3$ of the companies in the top 500 list of Fortune magazine in 1970 have disappeared in a dozen years, and the problem is that the original core capabilities of these companies have lost their core roles along with the change of environment. To sum up, any one of the endogenous growth theory or exogenous growth theory could not provide a perfect theoretical framework for explaining the acquisition mechanism of sustainable competitive advantage.

The acquisition and consolidation of corporate sustainable competitive advantage should be coordinated by the two lines of external environment and internal capability. From the perspective of internal capability, with the rapid development of science and technology as well as the wide application of ICTs (Information and Communication Technologies), the market competition among enterprises not only focuses on the competition of product quality and price likewise in the traditional economy, but also concentrates on the value and particularity of technology. Technology innovation has become an inevitable choice for enterprises to achieve survival and development (Ravari et al., 2016). Weerawardena and Mavondo (2011) mentioned that in order to gain competitive advantage, enterprises should continue to launch new products on the basis of strong technological innovation capability. Such viewpoint is also verified by some empirical studies. For example, Baaij et al. (2004) found that technological innovation supports high-tech enterprise's continuous competitive advantage, through analyzing the data of world's top 500 high-tech enterprises engaged in computer hardware production. Similarly, the research result of Whrl et al. (2009), who investigated more than 80 technology companies in Germany, proves that the strength of technological innovation has a positive impact on the organizational growth. Furthermore, Yam et al. (2011) expounded the theory of technological innovation in accordance with the viewpoint of resource-based competition. They proposed that the technological innovation could mine, develop and utilize the potential value of internal resources, and therefore has the function to enhance competitive advantage.

From the external perspective, compared to the relatively stable and simple environment in the industrial era, nowadays corporations are facing a continuous changing and complex environment. When seeking for a way to construct strategic competitive advantage, many enterprises do not try to surpass and replace the outstanding competitors, but jump into a new field to construct differentiation competitive advantage (Sinfield et al., 2012). In the case, a creative, effective and efficient business model is of importance. In current practice, managers pay attention to not only product innovation but also business model design (Tollin, 2008). They usually take the business model innovation as the central task of their strategic decision making (Aspara et al., 2010), since business model innovation reflects an increasing potential for helping enterprises gain competitive advantage in the new economic era (Visnjic et al., 2016; Lambert and Davidson, 2013). Moreover, compared with technological and product innovation, business model innovation can lead to enterprise's stable and strong advantage with high and sustainable returns in dynamic environment (Kim and Min, 2015), because the imitation of business model is also quite challenging. Through a study of 190 listed companies in United States and Europe, Amit and Zott (2012) proved that even in the context of environmental change, the innovation-centered 
business model does have a positive impact on the competitive advantage of enterprises.

According to the above mentioned analysis, for one thing, technological innovation supports the creation of new products or services and the establishment of corporate technological advantages (Drazin and Schoonhoven, 1996); combining innovative production management and marketing management, enterprises can effectively reduce the costs of production and sales, and further achieve their cost leadership strategies (Ren et al., 2009). For another, business model innovation can not only enable enterprises better adapt to the changes of market demand, which would improve customer satisfaction and enhance customer's perceived value, but also help enterprises to develop and utilize market opportunities, which would be beneficial to the improvement of marketing capability and the implementation of differentiation competitive strategy (Naidoo, 2010). It can be seen that whether enterprises focus on either technological innovation or business model innovation would be invalid, but the virtuous interaction between both of them could support the achievement of sustainable competitive advantage. In summary, enterprises need to build a new dual innovation system, through integrating technological innovation and business model innovation, to realize the sustainable development.

Therefore, we propose two hypotheses as follows:

H1. Technological innovation has positive effect on sustainable competitive advantage, and

$\mathrm{H} 2$. Business model innovation has positive effect on sustainable competitive advantage.

\subsection{Intellectual capital}

Since Galbrainth and Bryant (1969) first proposed the concept of intellectual capital, scholars have conducted extensive research on its connotation and components. Although there does not have an unified opinion on the definition of intellectual capital, it is generally agreed that intellectual capital is a kind of capital created by the intellectual activities that can bring value added to enterprises (Chen et al., 2014). The research on the components of intellectual capital can be classified into theoretical clusters, i.e. dualism, trilism and pluralism. Scholars with dualism theory generally divide intellectual capital into human capital and structural capital (Firer and Williams, 2003); trilism theory usually analyzes the intellectual capital from perspectives of human capital, organizational capital, and social capital (Reed et al., 2010), and pluralists often attach intellectual capital to intangible capital based on an expansive explanation, correspondingly all components of intangible asset are also categorized as intellectual capital (Johnson, 1999).

Aghion and Howitt (1992) built a model of technological innovation and in this study, they believed that technological innovation is an im- portant motive force to promote corporate growth. Prahalad and Hamel (1990) proposed the core competence theory, and considered that core competence is the most significant driver of corporate sustainable development. In essence, there is a high internal consistency between the above two constructs, and the core competence is often characterized as technology-based. Further analysis of the antecedents of technological innovation and core competence reveals that intellectual capital is a fundamental driving factor in the innovative growth path of modern enterprises (Yao and Dong, 2010).

Nonaka and Toyama (2003) stated that the success of technological innovation is not only dependent on whether the enterprise is competitive in the market, but also whether it has the key knowledge resources in a certain field of technology. According to the study of Lichtenberg (2001), intellectual capital promoted technological innovation capability by directly affecting corporate R\&D input and indirectly affecting the absorptive capacity of external technology. Through empirical studies, Subramaniam and Youndt (2005) and Hsu and Fang (2009) confirmed that the effective intellectual capital management could significantly improve the technological innovation capability.

Furthermore, Jardon and Gonzalezloureiro (2013) proposed that the direct management effect of intellectual capital development is the helpful role in the formation of core competence, which catches great attention of modern enterprises. Through supporting knowledge creation and technological innovation, intellectual capital plays role in organization's competence in global value chain. Similarly, Wang et al. (2014) constructed a model and found that managers should invest and leverage intellectual capital to gain competitive advantage. Intellectual capital, especially the tacit knowledge condensed in complex organizational process or hidden in human brain, is unique, valuable and inimitable, it thus becomes the most effective driver for the establishment of continuous competitive advantage (Spanos et al., 2010). Likewise the discussion of Nonaka and Toyama (2003), the essence of organization is a learning system that creates, acquires and utilizes knowledge. Enterprises can enhance their technological innovation capabilities, which benefits sustainable development, through creating knowledge, internalizing it and then externalizing it as financial performance. Based on the above consideration, we supplement two new hypotheses:

H3. Intellectual capital has positive effect on technological innovation, and

H4. Technological innovation plays a mediating role in the impact of intellectual capital on sustainable competitive advantage. 


\subsection{Corporate character}

The construct of corporate character has been existed for a long time, however up to now, scholars are differing in their understanding of its connotation and dimensions, which are shall be different in various cultural contexts. Shee and Abratt (1986) early defined the corporate character as the sum of unique organizational behaviours and intellectual characteristics. From the perspective of organizational governance, Moore (2015) proposed that the corporate character is a relatively broad concept, including differentiated corporate strategy, specific corporate culture, unique employee personality, and heterogeneous product positioning and so on. Slaughter et al. (2004) regarded the character of an organization as its personality trait, similar to human personality, that is perceived by the outside world, including the stakeholders such as customer, cooperator, competitor and investor. In the same year, on the basis of a survey, she completed an exploratory factor analysis of 255 selected terms associated with organizational personality and extracted five dimensions, including Boy Scout, innovativeness, dominance, thrift and style. Similarly, Yu et al. (2018) summarized and proposed six dimensions of organizational character, which includes enterprise, conscientiousness, innovation, agreeableness, democracy and Boy Scout, based on a survey of 205 observations in Chinese context.

Facing increasingly fierce market competition, enterprises are forced to constantly show an unique characteristic trait, in order to be differentiated from their competitors. However, even facing similar or even the same changes of external environment, enterprises may have different differentiation competitive strategy and then meet totally different destinies. The differences in strategy choice and competitive behaviour among enterprises are dependent on their discrepant corporate characters (Coutinho and Moraes, 2015). The differentiation competitive strategy dominated by corporate character has become an important tool for some enterprises to strike the existing market equilibrium and create novel opportunities for developing competitive advantage. Among the few related studies, Love and Kraatz (2009) have demonstrated that an appropriate corporate character could contribute to the long-term sustainable development via the mediating role of corporate reputation. Church et al. (2015) explored the relationship between corporate character and enterprise development. He found that the role of organizational character in enterprise's development is often ignored or underestimated; however, there does exist a significant correlation between them.

While enterprises are focusing on cultivating personality traits and implementing differentiation strategy, they should also pay great attention to the important role of business model innovation, which bridges the impacting path from corporate character to sustainable competitive advantage. However, the fact is that in previous studies, researchers focused too much on the impacts of formal institutions on technological innovation, on the contrary, less attention was paid to the relationship between informal institutions (e.g. corporate character) and non-technical innovation (e.g. business model innovation). Whereas Scott and Bruce (1994) found that non-technical innovation is the result of interaction among individuals, leaders, work teams and organizational climate, which are the embodiment of corporate character and reflect the role of informal institutions. Informal social relations and tacit knowledge promote the exchange and integration of production resources, thus contribute to the realization and evolution of business model.

Regarding to the specific dimensions of corporate character, a few of research results can prove their significant roles. For example, Everdingen and Waarts (2003) found that business model innovation is more likely to occur in a non-bureaucratic environment with low power distance, that is, democracy may raise creative activities. Since no one can have all the knowledge needed in the process of business model innovation, employees' cooperation in terms of knowledge creation and integration is necessary to the achievement of business model design. Horng et al. (2011) proposed that the harmonious working atmosphere, which may promote social psychological factors (e.g. intrinsic motivation), would have a fundamental impact on business model innovation. Khoja and Maranville (2010) also pointed out that enterprising, one dimension of the corporate character, which is characterized by daring to challenges and taking risks, has the function to encourage employees to actively absorb external useful knowledge to create or update business model for enterprises. Hence, the added hypotheses are as follows:

H5. Corporate character has positive effect on business model innovation, and

H6. Business model innovation plays a mediating role in the impact of corporate character on sustainable competitive advantage.

\subsection{The correlation between intellectual capital and corporate character}

As hot topics in enterprise strategic management, intellectual capital and corporate character have attracted wide attention from scholars. However, as two important aspects affecting sustainable competitive advantage, the research linking them together is rare. Nonetheless, management theories and practices continuously remind us that the two should have a correlation logically and enterprises may construct sustainable competitive advantage through their joint effects. The logic may be described as follows: enterprises design initial business model, win the market and gain temporary competitive advantage by shaping unique character traits; then they can increase investment in R\&D activities and support large-scale technological innovation, intellect- 
tual capital is thus created and accumulated for the enhancement of core competence and even sustainable competitive advantage; enterprises grow in strength, and in turn transfer to cultivate high-end and friendly corporate character, which would be embodied in premium brand, good reputation and benign image, etc. For example, Zabala et al. (2005) proposed that when an enterprise's input of intellectual capital is perceived and recognized by the public, it would form a technology-intensive social reputation, a dimension of externalized corporate character, which would play an active role in the promotion of financial performance (through the mediating role of customer trust) and potential performance in the capital market (through the mediating role of potential investor trust); reversely, the high performance would motivate the enterprise and improve its capabilities in intellectual capital investment. We therefore put forward a new hypothesis: $\mathrm{H} 7$. There is significant correlation between intellectual capital and corporate character.

\subsection{Research framework}

As the analysis mentioned above, sustainable competitive advantage, which is the ultimate goal of organizations in competitive markets, can be led by the new dual innovation system that contains technological innovation and business model innovation, which are further driven by intellectual capital and corporate character. Summarizing the above five hypotheses, we can build a theoretical framework model (see Figure 1) to illustrate the correlative relationships among the concepts.

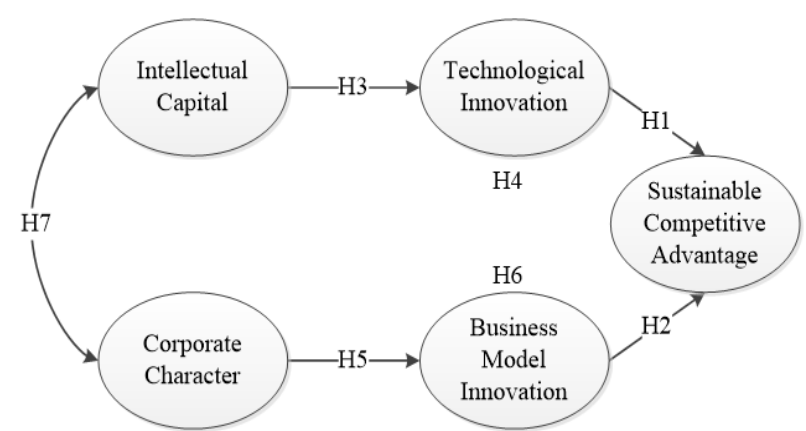

Figure 1. Theoretical framework model

\section{Methodology}

\subsection{Measures}

Sustainable competitive advantage (SCA) reflects that an enterprise takes an unique strategy to gain interests, which cannot be easily imitated or copied by its competitors, so that the interests would be remained at a certain level for a long time. This construct can be decomposed into three dimensions: efficiency (Ef), capability (Ca), and sustainability $\mathrm{(Su})$. The dimensions were developed based on the work of Liu (2017) and Guimarães and Severo (2018).
Intellectual capital (IC) reflects a knowledge resource owned or controlled by an enterprise, to which it can bring value added, including the implicit knowledge embedded in the organization, institutions and employees, as well as the explicit knowledge that can be structured and represented (Braunerhjelm et al., 2018). According to the studies of Subramaniam and Youndt (2005) and Liu (2017), IC can be measured with three constructs regarding internal and external resources, i.e. human capital (HC), organizational capital (OrC), and social capital (SC).

Corporate character (CC) reflects the common characteristic of different individuals in an enterprise, and this characteristic can be usually identified by the bodies in outside world, so that it forms one of the key differences between the enterprise and other organizations (Yu et al., 2015). Based on this study, $\mathrm{Yu}$ et al. (2018) further measured the CC with six dimensions, which include enterprise (En), conscientiousness (Co), innovation (In), agreeableness $(\mathrm{Ag})$, democracy (De) and Boy Scout (BS). Furthermore, the six dimensions are assessed by items adapted from Ali and Park (2016), Palmer et al. (2017), Martin et al. (2017) and Shafat and Nasir (2018).

Technological innovation (TI) refers to the process of commercialization of new products and new processes. This study measures TI based on the work of Ali and Park (2016), with two aspects: product innovation (PdI) and process innovation (PcI).

Business model is a value creation system in a constantly changing environment. This system consists of many factors such as value proposition, target customer, operation process, allocation of resources, marketing channel and so on. The business model innovation (BMI) is the transformation for the content or the combination of these factors (Osterwalder and Pigneur, 2012). In this study, BMI would be measured, to assess the newness of the business model in terms of the predefined core elements, with three indices: value offering architecture (VOA), value creation architecture (VCA) and financial architecture (FA) (Amit and Zott, 2012; Futterer et al., 2018).

In order to effectively represent the first-order constructs, two formative items are selected employed to measure each of them, by using 5-point Likert scales, where 1 represents strongly disagree and 5 represents strongly agree.

\subsection{Data}

In order to realize this study, a total of 840 questionnaires are randomly sent out through the Sojump website (www.sojump.com), which is a professional service institution for questionnaire survey in China. It can reach a large number of high quality questionnaires in a short time through a variety of online recycling channels. Many Chinese scholars have successfully sought help from it during their academic research processes (Rui, 2017; Che and Cao, 2014). 
Table 1 . Reliability and validity test

\begin{tabular}{|c|c|c|c|c|c|}
\hline Latent variable & Measurement variable & Factor loading & Cronbach's alpha & $\mathrm{CR}$ & AVE \\
\hline \multirow{3}{*}{ SCA } & Ef & $0.63 * * *$ & \multirow{3}{*}{0.67} & \multirow{3}{*}{0.80} & \multirow{3}{*}{0.58} \\
\hline & $\mathrm{Fu}$ & $0.82 * * *$ & & & \\
\hline & $\mathrm{Su}$ & $0.81 * * *$ & & & \\
\hline \multirow{3}{*}{ IC } & $\mathrm{HC}$ & $0.73 * * *$ & \multirow{3}{*}{0.66} & \multirow{3}{*}{0.81} & \multirow{3}{*}{0.60} \\
\hline & OrC & $0.83 * * *$ & & & \\
\hline & $\mathrm{SC}$ & $0.75 * * *$ & & & \\
\hline \multirow{6}{*}{$\mathrm{CC}$} & En & $0.61 * * *$ & \multirow{6}{*}{0.66} & \multirow{6}{*}{0.86} & \multirow{6}{*}{0.50} \\
\hline & $\mathrm{Co}$ & $0.77 * * *$ & & & \\
\hline & In & $0.70 * * *$ & & & \\
\hline & $\mathrm{Ag}$ & $0.65 * * *$ & & & \\
\hline & BS & $0.67 * * *$ & & & \\
\hline & De & $0.82 * * *$ & & & \\
\hline \multirow{2}{*}{ TI } & PdI & $0.84 * * *$ & \multirow{2}{*}{0.61} & \multirow{2}{*}{0.83} & \multirow{2}{*}{0.71} \\
\hline & PcI & $0.84 * * *$ & & & \\
\hline \multirow{5}{*}{ BMI } & VOA & $0.79 * * *$ & \multirow{5}{*}{0.73} & \multirow{5}{*}{0.84} & \multirow{5}{*}{0.63} \\
\hline & VCA & $0.80 * * *$ & & & \\
\hline & FA & $0.79 * * *$ & & & \\
\hline & $\mathrm{Fu}$ & $0.82 * * *$ & & & \\
\hline & $\mathrm{Su}$ & $0.81 * * *$ & & & \\
\hline
\end{tabular}

Table 2. Discriminant validity

\begin{tabular}{|l|c|c|c|c|c|}
\hline Variables & SCA & IC & CC & TI & BMI \\
\hline SCA & 0.76 & & & & \\
\hline IC & $0.41 * * *$ & 0.77 & & & \\
\hline CC & $0.43 * * *$ & $0.65 * * *$ & 0.71 & & \\
\hline TI & $0.43 * * *$ & $0.31 * * *$ & $0.37 * * *$ & 0.84 & \\
\hline BMI & $0.50 * * *$ & $0.43 * * *$ & $0.58 * * *$ & $0.49 * * *$ & 0.79 \\
\hline
\end{tabular}

Note: The diagonal data are the square root values of AVE; the non-diagonal data are the correlation coefficients between the variables. $\quad * * * . \mathrm{P}<0.01 ; * * . \mathrm{P}<0.05 ; * . \mathrm{P}<0.10$

From April $3^{\text {rd }}$ and April $10^{\text {th }}$ in 2018, 480 copies were collected. After eliminating the invalid questionnaires that excessive entries are omitted or the respondent's attitude is not good enough (e.g. selecting the same option for the vast majority of questions), we finally obtain 377 valid questionnaires yielding the effective response rate of $45 \%$.

With regards to the basic information of samples, there are more than $70 \%$ of the participants in the sample have a bachelor's degree and have worked in their companies for more than 3 years. This ensures that the participants have a perception with long enough time and a relatively mature understanding of their enterprises. The participants are distributed over 27 provincial areas in Chinese mainland.

\subsection{Reliability and validity}

A confirmative factor analysis (CFA) is conducted to test the psychometric properties of the scales. As shown in Table 1, the measurement results indicate that the data fit well. Li et al. (2014) asserted that factor loading is an important indication of construct validity for each measured items, and the values should be greater than 0.6. As shown in the Table 1, all factor loadings of the items are above this threshold, within the range from 0.61 to 0.84 , which indicate that the intrinsic quality of the model is well tested and the selected level is suitable for the measurement of latent variables. Drawn from Table 2, the diagonal data (square root values of AVE) are all higher than their corresponding non-diagonal data 
(correlation coefficients). Therefore, the discriminant validity of the measurement is acceptable.

According to the Table 1, The values of Cronbach's alpha of this study range from 0.61 to 0.73 . The results indicate that the measures of the constructs are reliable. In addition, the composite reliability (CR) coefficients are all greater than 0.80 , which are also greater than the recommended standard 0.70 (Chen and Pearl, 2015). Average variance extracted (AVE) is used to measure the reliability of individual observations and composite unobservables compared with the error variance, and its value is recommended to be above 0.5. In this study, the values of AVE are all surpass the recommended standard.

\subsection{Common method bias}

The questionnaire is developed, pretested and distributed in Chinese. Procedural remedies are combined to control for common method bias. With respect to the former remedies, all independent and dependent variables are separated in the questionnaire and corresponding items are kept as simple as possible to reduce the vagueness of the construction of each item (Jones et al., 2003). Further procedural measures taken to remedy common method variance are to assure respondents' anonymity and confidentiality as well as to point out that there is no right or wrong in giving their answers (Chang et al., 2010).

According to the recommendation of Guide and Ketokivi (2015) and research design of Jia et al. (2018), we use Harman's single factor test to evaluate the level of common method bias. In this research, all the items of latent variables are subjected to a factor analysis. The explained variance of the first factor among the five factor values with initial eigenvalues larger than 1 is $24.96 \%$, less than the commended $40 \%$. Thus, the common method bias should not be a significantly concerned problem in this study.

\subsection{Methods}

This study takes the structural equation model (SEM) to measure the relationships among the latent variances and test the hypotheses. In addition, the significant mediating roles are tested by Bootstrap procedure.

\section{Results}

The study tests the proposed framework model by using the SEM method, which is solved by the tool of AMOS 18. The estimated standardized path is displayed as Figure 2. The overall model fit of the proposed model $(\mathrm{CMIN} / \mathrm{DF}=2.60<5, \mathrm{PCFI}=0.75>0.50$, $\mathrm{IFI}=0.91>0.90, \quad$ GFI $=0.91>0.90, \quad \mathrm{RMSEA}=0.065<$ $0.08, \mathrm{RMR}=0.059<0.08$ ) is acceptable.

The estimated parametric significance gives valuable information about the correlation among variables in this study. The criteria either to accept or re- ject hypotheses proposed is 0.01 . That is, if $\mathrm{p}<0.01$, the hypothesis is accepted, else the original hypothesis should be rejected. The results of estimated output value can be seen in the Figure 2. With regards to the path coefficients and their respective significance levels, all hypotheses find empirical support. More specifically, hypothesis H1 is supported, since TI makes a significantly positive effect towards SCA (0.604, p < 0.01). Similarly, hypothesis H2 is supported as BMI makes a positive and significant impact on SCA $(0.391, \mathrm{p}<0.01)$. Both the hypothesis H3 $(0.692, p<0.01)$ and H5 $(0.827, p<0.01)$ meet the test, which verify that IC and CC are really important antecedent drivers of dual innovation system. Furthermore, the significant correlation $(0.117, \mathrm{p}<$ $0.01)$ between IC and CC indicates that the hypothesis $\mathrm{H} 7$ is supported too.

In order to test the potential mediation effects, subsequently common procedures in structural equation modeling are applied (Jr et al., 2013); that is, we try to develop the bootstrapping approach suggested by Preacher and Hayes (2008). Initially, 2000 bootstrap samples are extracted from the original data $(\mathrm{N}=377)$ by repeated random sampling, and the path values of the mediation effect and the confidence interval of $95 \%$ are calculated. The results are shown in Table 3 . As shown in the table, the $95 \%$ confidence intervals of the two paths do not include 0 . The fact indicates that the mediating effects of these two indirect paths are all significant. In conclusion, the results confirm the establishment of a mediation for the effect of IC on SCA via TI, and also confirm the establishment of a mediation for the effect of CC on SCA via BMI. Hence, the hypotheses $\mathrm{H} 4$ and $\mathrm{H} 6$ are supported by empirical evidences.

\section{Discussion}

\subsection{The role of intellectual capital}

According to the results, among the three elements of intellectual capital, the order of strength for promoting sustainable competitive advantage is: organizational capital, social capital and human capital $\left(0.688^{* * *}>0.577 * * *>0.525 * * *\right)$, which is different from the research of Subramaniam and Youndt (2005) based on the sample of American enterprises. The reason may be that relative to the leading enterprises in developed countries, most of the enterprises in China in new economic environment belong to latecomer, of which small and medium-size enterprises account for the majority. The results suggest that enterprises need to balance the development of the three elements of intellectual capital according to their own business conditions and management goals. In the path from technological innovation to sustainable competitive advantage, intellectual capital would be a continuous and effective power source. 


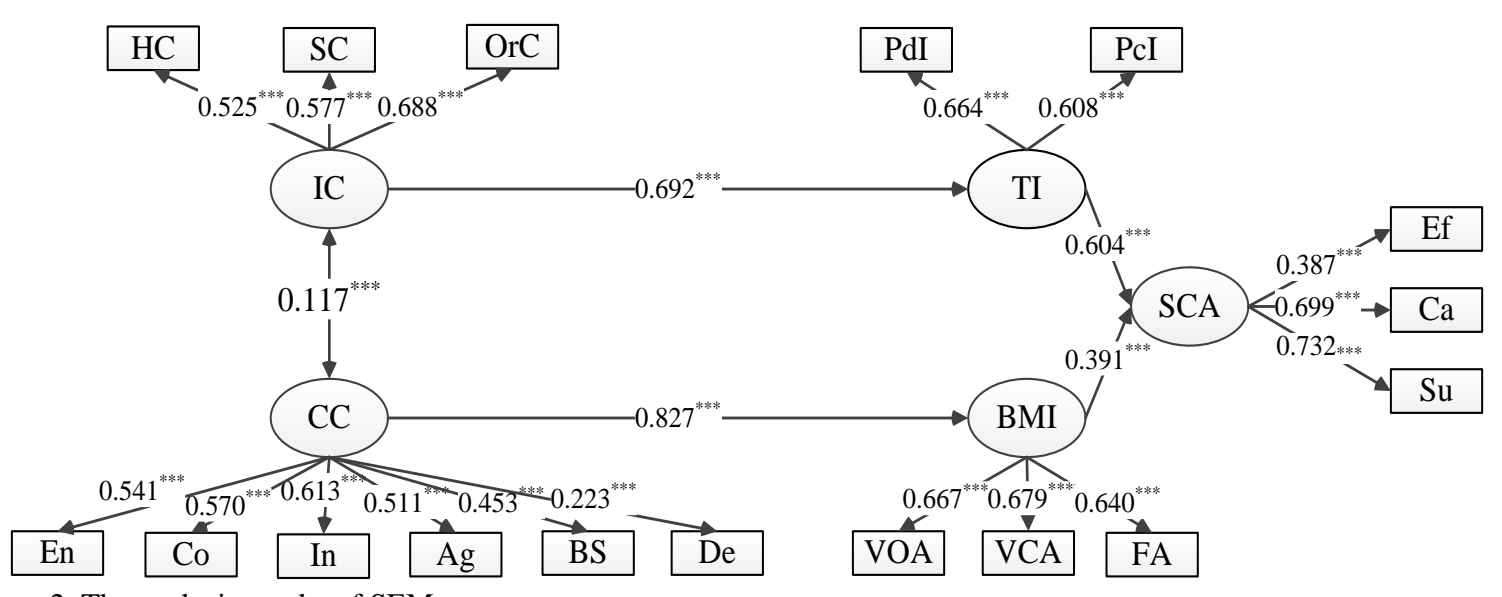

Figure 2. The analysis results of SEM

Table 3. Bootstrap analysis of mediating effects

\begin{tabular}{|c|c|c|c|}
\hline \multirow{2}{*}{$\begin{array}{c}\text { Indirect effect } \\
\text { paths }\end{array}$} & \multicolumn{3}{|c|}{ Confidence level=95\% } \\
\cline { 2 - 4 } & Estimate & Lower bounds & Upper bounds \\
\hline $\mathrm{IC} \rightarrow \mathrm{TI} \rightarrow \mathrm{SCA}$ & $0.692 * 0.604=0.418$ & 0.165 & 0.581 \\
\hline $\mathrm{CC} \rightarrow \mathrm{BMI} \rightarrow$ SCA & $0.837 * 0.391=0.327$ & 0.141 & 1.415 \\
\hline
\end{tabular}

\subsection{The role of corporate character}

All elements of corporate character make significantly positive impact on sustainable competition advantage. The result is consistent with the previous study (Yu et al., 2018). We believe that despite the different cultural and institutional backgrounds, these would not affect the role of corporate character in the improvement of competitive advantage.

Among the elements of corporate character, the most obvious effects are from innovation $\left(0.613^{* * *}\right)$ and democracy $\left(0.223^{* * *}\right)$ : the former plays the strongest role and the latter plays the weakest role in the path. According to the previous studies in the field of corporate character, in fact, the spirit of innovation is always thought as a fundamental and the most important component of corporate character. Democracy is scarce in most of Chinese enterprises, especially the state-owned enterprises, and required by their employees, but in practice most of them choose to build undemocratic environments in order to raise the efficiency of centralized decision-making. Because of the influence of Confucian culture in the past thousands of years, Chinese people indeed are not very disgusted with undemocratic work environments. However, along with the development of global economy, the democracy would become increasingly important in the constitution of corporate character.

In addition, other elements of corporate character, including conscientiousness $\left(0.570^{* * *}\right)$, enterprise $\left(0.541^{* * *}\right)$, agreeableness $\left(0.511^{* * *}\right)$ and Boy Scout $\left(0.453^{* * *}\right)$, plays similarly important role in promoting business model innovation and sustainable competitive advantage. This requires enterprises to construct dual culture: for one thing, they need to continuously stimulate their employees, through establishing conscientious, aggressive and united culture; for another, they need to show loving care for their employees, through establishing delightful, free and open culture. It is important to note here that corporate character is not equal to organizational culture, but it is an internalization and sublimation of culture in nature and can be improved through the optimization of organizational culture.

\subsection{The role of innovation}

Both intellectual capital and corporate character play a significant role in the path to reach sustainable competitive advantage, but their impacting strengths are different. Technological innovation plays stronger role in directly improving sustainable competitive advantage $(0.604 * * *)$, in comparison with the weaker role of business model innovation $(0.391 * * *)$. Obviously, though in the new economic era, which is characterized as fickle and creative, technological innovation is also the most important activity to assist in successful competition, the same as in the era of knowledge economy. However, whatever their impacting strengths, the results indicate us that we should consider to build a new dual innovation system, which integrates technological innovation and business model innovation together, to maximize enterprise's capability of gaining sustainable competitive advantage. In this dual innovation system, the integrating mechanism would be the key to continuously drive the system and realize its intended functions.

In addition, the impacting mechanisms of intellectual capital and corporate character on sustainable competitive advantage are also different. In the impacting path from intellectual capital to sustainable competitive advantage, the core mediator is technological innovation (the mediating effect is estimated as $0.418^{* * *}$ ); however, in the impacting path from corporate character to sustainable competitive advantage, business model innovation plays the medi- 
ating role (the mediating effect is estimated as $0.327 * * *)$. This result indicates us that the technological innovation and business model innovation have different functions in enterprises, and the impacting effect from intellectual capital to sustainable competitive advantage via technological innovation is slightly stronger than the impacting effect from corporate character to sustainable competitive advantage via business model innovation.

The two components of dual innovation system are all important, but their drivers are different. In general, technological innovation relies much on intellectual capital, while business model innovation relies much on corporate capital. Comparing with the various antecedents of technological innovation, for example, R\&D expenditure and research laboratory, the driver of business model innovation is less varied, and so the corporate character is more effective to drive it $(0.827 * * *>0.692 * * *)$. This reminds us that we need to build a management system for intangible assets, which contains intellectual capital and corporate character, to effectively drive the operation of dual innovation system and better maintain sustainable competitive advantage.

\subsection{The correlativity between intellectual capital and corporate character}

There is a correlative relationship between intellectual capital and corporate character $(0.117 * * *)$. It means that we can create intellectual capital driven by corporate character, and also can build corporate character driven by intellectual capital. The former impacting path makes intellectual capital unique and inimitable, and the latter impacting path makes corporate character knowledge-based and intellectual. This mechanism makes the two factors develop evenly in perfect union. This may be the real reason that the competitive advantage driven by them can be sustainable.

\subsection{The dualism of source of sustainable competitive advantage}

According to the analysis above, the growth of enterprises in the new economic environment depends on both the internal and external factors: on the one hand, it relies on technological innovation driven by intellectual capital, through which it creates a lowcost and high value-added strategy to achieve the endogenous core competence; on the other hand, it relies on business model innovation driven by corporate character. The innovation of business model raises the capability of adaptive adjustment to rapid changes in external environments, and helps enterprises create value-added strategy by providing heterogeneous products and services through creative channels. Business model innovation thus assists enterprises continuously obtain a temporary differentiated competitive advantage.

From the perspective of strategy management, it provides a valuable framework to explain the source of sustainable competitive advantage. In previous studies, the source of sustainable competitive advantage has attracted great attention, and therefore has formed many academic schools, such as resourcebased, capability-based and dynamic sustainability views. However, their common weakness is to explore the source of sustainable competitive advantage from single perspective. On contrary, this study presents a new viewpoint to explain the source; that is, the dualism of source of sustainable competitive advantage, which includes two formation paths. For one thing, enterprises could realize the differentiated advantage in market competition through business model innovation based on the attractiveness of corporate character; for another, they can set up the core competence based on technological innovation by strengthening the creation and operation of intellectual capital. The effective combination of temporary competitive advantage and core competence helps enterprises makes their advantages sustainable.

\section{Conclusions}

Based on the theory of competitive advantage, this paper focuses on the exploration of the antecedents and impacting paths, through which an enterprise can gain and maintain its sustainable competitive advantage. On the basis of seven hypotheses and theoretical framework, we use structural equation model to observe the impacting paths from intellectual capital and corporate character to sustainable competitive advantage via the mediating role of innovation. By analyzing the sample data of 377 questionnaires from Chinese enterprises, we find that intellectual capital significantly promotes the sustainable competitive advantage through the mediating role of technological innovation, and similarly business model innovation significantly plays mediating role in the effect of corporate character on sustainable competitive advantage. In addition, there is a coupling, co-evolutionary and complex relationship between intellectual capital and corporate character. This study reveals that two paths can lead to sustainable competitive advantage, thus we present a dual theory to explain the source of sustainable competitive advantage. According to the research results, we are inspired that in the long run enterprises need to make full use of the effective combination of intellectual capital and corporate character, and seek the coordination and balance of them, just like two legs to walk, to maximize the organizational capability of sustainable innovation-based growth.

The dual system of sustainable competitive advantage, unlike the previous theories from single perspective in the field, observes the external and internal growth paths and considers to integrate them through the tongs of intellectual capital and corporate character. Intellectual capital, which reflects the core resources and capabilities of enterprises, sup- 
ports the internal growth mechanism; while corporate character, which reflects the popularity degree of enterprise's heterogeneity, supports the external growth mechanism. This new theory indeed integrates the key viewpoints of previous theories such as resource-based, knowledge-based, and capabilitybased views. Facing the new economic environment characterized by knowledge-based, changeful and personalized, the dual theory can provide much more explanatory power.

The study provides empirical evidences for the establishment of a new theory. This theory integrates some previous theories together, such as dual innovation and the source of sustainable competitive advantage, and its management measurement focuses on the integration of intellectual capital and corporate character. We hope this theory to be explanatory for the new growth mechanism of enterprises in the new economic environment.

\section{Acknowledgments}

This work was supported by the National Natural Science Foundation of China (Grants No. 71563027; 71962021).

\section{References}

1. AGHION P., HOWITT P., 1992, A Model of Growth Through Creative Destruction, in: Econometrica, 60(2), p. 323-351.

2. ALI M., PARK, K., 2016, The Mediating Role of an Innovative Culture in the Relationship Between Absorptive Capacity and Technical and Non-technical Innovation, in: Journal of Business Research, 69(5), p. $1669-1675$.

3. AMIT R., ZOTT C., 2012, Creating Value Through Business Model Innovation, in: MIT Sloan Management Review, 53(3), p. 41-49.

4. ASPARA J., HIETANEN J., TIKKANEN H., 2010, Business Model Innovation vs Replication: Financial Performance Implications of Strategic Emphases, in: Journal of Strategic Marketing, 18(1), p. 39-56.

5. BAAIJ M., GREEVEN M. DALEN J. V., 2004, Persistent Superior Economic Performance, Sustainable Competitive Advantage, and Schumpeterian Innovation: Leading Established Computer Firms, 19542000, in: European Management Journal, 22(5), p. 517-531.

6. BAUM J.A.C., DOBBIN F., 2016, Firm Resources and Sustained Competitive Advantage, in: Journal of Management, 17(1), p. 3-10.

7. BRAUNERHJELM P., DING D., THULIN P., 2018, The Knowledge Spillover Theory of Intrapreneurship, in: Small Business Economics, 51(1), p. 1-30.

8. CHANG S.J., WITTELOOSTUIJN A.V., EDEN L., 2010, From the Editors: Common Method Variance in International Business Research, in: Journal of International Business Studies, 41(2), p. 178-184.

9. CHE H.L., CAO Y., 2014, Examining WeChat Users' Motivations, Trust, Attitudes, and Positive Word-of-mouth: Evidence from China, in: Computers in Human Behavior, 41, p. 104-111.

10. CHEN B., PEARL J., 2015, Graphical Tools for Linear Structural Equation Modeling, Technical Report, R-432, http://ftp.cs.ucla.edu/pub/stat_ser/r432.pdf.
11. CHEN C.J., LIU T.C., CHU M.A., HSIAO Y.C., 2014, Intellectual Capital and New Product Development, in: Journal of Engineering \& Technology Management, 33, p. 154-173.

12. CHURCH A.H., ROTOLO C.T., MARGULIES A. et al., 2015, The Role of Personality in Organization Development: A Multi-level Framework for Applying Personality to Individual, Team, and Organizational Change, in: Research in Organizational Change \& Development, 23, p. 91-166.

13. COUTINHO L.R., MORAES B.R.S., 2015, Organizational Gameplay: The Player as Designer of Character Organizations, in: International Journal of Computer Games Technology, 2015, Paper No. 731031.

14. DRAZIN R., SCHOONHOVEN C.B., 1996, Community, Population, and Organization Effects on Innovation: A Multilevel Perspective, in: Academy of Management Journal, 39(5), p. 1065-1083.

15. EVERDINGEN Y.M.V., WAARTS E., 2003, The Effect of National Culture on the Adoption of Innovations, in: Marketing Letters, 14(3), p. 217-232.

16. FIRER S., WILLIAMS S.M., 2003, Intellectual Capital and Traditional Measures of Corporate Performance, in: Journal of Intellectual Capital, 4(3), p. 348-360.

17. FUTTERER F., SCHMIDT J., HEIDENREICH S., 2018, Effectuation or Causation as the Key to Corporate Venture Success? Investigating Effects of Entrepreneurial Behaviors on Business Model Innovation and Venture Performance, in: Long Range Planning, 51(1), p. 64-81.

18. GUIDE V.D.R., KETOKIVI M., 2015, Notes from the Editors: Redefining Some Methodological Criteria for the Journal, in: Journal of Operations Management, 37(1), p. 5-8.

19. GUIMARÃES J.C.F.D., SEVERO E.A., 2018, The Influence of Entrepreneurial, Market, Knowledge Management Orientations on Cleaner Production and the Sustainable Competitive Advantage, in: Journal of Cleaner Production, 174, p. 1653-1663.

20. HORNG J.S., HU M.L., HONG J.C., LIN Y.C., 2011, Innovation Strategies for Organizational Change in a Tea Restaurant Culture: A Social Behavior Perspective, in: Social Behavior \& Personality: An International Journal, 39(2), p. 265-273.

21. HSU Y.H., FANG W., 2009, Intellectual Capital and New Product Development Performance: The Mediating Role of Organizational Learning Capability, in: Technological Forecasting \& Social Change, 76(5), p. 664-677.

22. JARDON C.M., GONZALEZLOUREIRO M., 2013, Human Capital as Source for Sustained Competitive Advantages in SMEs: A Core Competencies Approach, in: Economia Seria Management, 16(2), p. 255-276.

23. JIA X., CHEN J., MEI L., WU Q., 2018, How Leadership Matters in Organizational Innovation: A Perspective of Openness, in: Management Decision, 56(1SI), p. 6-25.

24. JOHNSON W.H.A., 1999, Integrative Taxonomy of Intellectual Capital: Measuring the Stock and Flow of Intellectual Capital Components in the Firm, in: International Journal of Technology Management, 18(5-8), p. 562-575.

25. JONES G., 2003, A Critical Review of Construct Indicators and Measurement Model Misspecification in 
Marketing and Consumer Research, in: Journal of Consumer Research, 30(2), p. 199-218.

26. JR J.F.H., RINGLE C.M., SARSTEDT M., 2014, Partial Least Squares Structural Equation Modeling: Rigorous Applications, Better Results and Higher Acceptance, in: Long Range Planning, 47(6), p. 392392.

27. KHOJA F., MARANVILLE S., 2010, How Do Firms Nurture Absorptive Capacity?, in: Journal of Managerial Issues, 22(2), p. 262-278.

28. KIM S.K., MIN S., 2015, Business Model Innovation Performance: When Does Adding a New Business Model Benefit an Incumbent?, in: Strategic Entrepreneurship Journal, 9(1), p. 34-57.

29. LAMBERT S.C., DAVIDSON R.A., 2013, Applications of the Business Model in Studies of Enterprise Success, Innovation and Classification: An Analysis of Empirical Research from 1996 to 2010, in: European Management Journal, 31(6), p. 668-681.

30. LI Y., CHEN H., LIU Y., PENG M.W., 2014, Managerial Ties, Organizational Learning, and Opportunity Capture: A Social Capital Perspective, in: Asia Pacific Journal of Management, 31(1), p. 271-291.

31. LICHTENBERG F., 2001, Does Foreign Direct Investment Transfer Technology Across Borders?, in: Review of Economics \& Statistics, 83(3), p. 490-497.

32. LIPPMAN S.A., RUMELT, R.P., 1982, Uncertain Imitability: An Analysis of Inter Firm Differences in Efficiency Under Competition, in: Bell Journal of Economics, 13(2), p. 418-438.

33. LIU C.H., 2017, Creating Competitive Advantage: Linking Perspectives of Organization Learning, Innovation Behavior and Intellectual Capital, in: International Journal of Hospitality Management, 66, p. 1323.

34. LOVE E.G., KRAATZ M., 2009, Character, Conformity, or the Bottom Line? How and Why Downsizing Affected Corporate Reputation, in: Academy of Management Journal, 52(2), p. 314-335.

35. MARTIN H., ERKAN O., MARKUS T., 2017, Do Corporate Image and Reputation Drive Brand Equity in India and China? Similarities and Differences, in: Journal of Business Research, in press, doi: org/10.1016/j.jbusres.2017.09.018.

36. MOORE G., 2015, Corporate Character, Corporate Virtues, in: Business Ethics A European Review, 24(S2), p. S99-S114.

37. NAIDOO V., 2010, Firm Survival Through a Crisis: The Influence of Market Orientation, Marketing Innovation and Business Strategy, in: Industrial Marketing Management, 39 (8), p. 1311-1320.

38. NILSSEN J., BERTHEUSSEN B.A., DREYER B., 2015, Sustained Competitive Advantage Based on High Quality Input, in: Marine Policy, 52, p. 145154.

39. NONAKA I., TOYAMA R., 2003, The Knowledgecreating Theory Revisited: Knowledge Creation as a Synthesizing Process, in: Knowledge Management Research \& Practice, 1(1), p. 2-10.

40. OSTERWALDER A., PIGNEUR Y., 2012, Designing Business Models and Similar Strategic Objects: The Contribution of IS, in: Journal of the Association for Information Systems, 14(5), p. 237-244.

41. PALMER C., STÖCKMANN C., NIEMAND T. et al., 2017, The Interplay of Entrepreneurial Orientation and Psychological Traits in Explaining Firm Per- formance, in: Journal of Business Research, in press, doi: 10.1016/j.jbusres.2017.10.005.

42. PORTER M.E., MILLAR V.E., 1995, How Information Gives You Competitive Advantage, in: Harvard Business Review, 36(4), p. 149-174.

43. PREACHER K.J., HAYES A.F., 2008, Asymptotic and Resampling Strategies for Assessing and Comparing Indirect Effects in Multiple Mediator Models, in: Behavior Research Methods, 40(3), p. 879891.

44. PRAHALAD C.K., HAMEL G.T., 1990, The Core Competence of the Organization, in: Harvard Business Review, 68(3), p. 79-91.

45. PRAHALAD C.K., HAMEL G.T., 2000, Chapter $1-$ The Core Competence of The Corporation, in: Strategic Learning in A Knowledge Economy, 3, p. 3-22.

46. RANJITH V.K., 2016, Business Models and Competitive Advantage, in: Procedia Economics \& Finance, 37, p. 203-207.

47. RAVARI S.S.M., MEHRABANFAR E., BANAITIS A., BANAITIENĖ N., 2016, Framework for Assessing Technological Innovation Capability in Research and Technology Organizations, in: Journal of Business Economics \& Management, 17(3), p. 825847.

48. REED K.K., LUBATKIN M., SRINIVASAN N., 2010, Proposing and Testing an Intellectual Capitalbased View of the Firm, in: Journal of Management Studies, 43(4), p. 867-893.

49. REN L., XIE G., KRABBENDAM K., 2009, Sustainable Competitive Advantage and Marketing Innovation Within Firms: A Pragmatic Approach for Chinese Firms, in: Management Research Review, 33(1), p. 79-89.

50. RESNICK J.T., 2003, Character is Foundation of Firm's Reputation, in: U.S. Banker, 113(3), p. 24-26.

51. RUI Y., 2017, Research on Customer to Customer Interaction Behaviors in Virtual Brand Community Based on Critical Incident Technique, in: Soft Science, 31(3), p. 120-124.

52. SCOTT S.G., BRUCE R.A., 1994, Determinants of Innovative Behavior: A Path Model of Individual Innovation in the Workplace, in: Academy of Management Journal, 37(3), p. 580-607.

53. SENGE P.M., 1992, The Fifth Discipline, in: Measuring Business Excellence, 4(3), p. 206-207.

54. SHAFAT M., NASIR Z., 2018, Corporate Social Responsibility and Financial Performance: An Empirical Analysis of Indian Banks, in: Science Direct, 4, p. 84-94.

55. SHEE P.S.B., ABRATT R., 1986, A New Approach to The Corporate Image, IEEE Computer Society Press, Washington, D.C.

56. SINFIELD J.V., CALDER E., MCCONNELL B., COLSON S., 2012, How to Identify New Business Models, in: MIT Sloan Management Review, 53(2), p. 85-90.

57. SLAUGHTER J.E., ZICKAR M.J., HIGHHOUSE S. et al., 2004, Personality Trait Inferences About Organizations: Development of a Measure and Assessment of Construct Validity, in: Journal of Applied Psychology, 89(1), p. 85-103.

58. SPANOS Y.E., ZARALIS G., LIOUKAS S., 2010, Strategy and Industry Effects on Profitability: Evidence from Greece, in: Strategic Management Journal, 25(2), p. 139-165. 
59. SUBRAMANIAM M., YOUNDT M.A., 2005, The Influence of Intellectual Capital on the Types of Innovative Capabilities, in: Academy of Management Journal, 48(3), p. 450-463.

60. TEECE D.J., PISANO G., SHUEN A., 2015, Dynamic Capabilities and Strategic Management, in: Strategic Management Journal, 18(7), p. 509-533.

61. TOLLIN K., 2008, Mindsets in Marketing for Product Innovation: An Explorative Analysis of Chief Marketing Executives' Ideas and Beliefs About How to Increase Their Firms' Innovation Capability, in: Journal of Strategic Marketing, 16(5), p. 363-390.

62. VISNJIC I., WIENGARTEN F., NEELY A., 2016, Only the Brave: Product Innovation, Service Business Model Innovation, and Their Impact on Performance, in: Journal of Product Innovation Management, 33(1), p. 36-52.

63. WANG Z., WANG N., LIANG H., 2014, Knowledge Sharing, Intellectual Capital and Firm Performance, in: Management Decision, 52(2), p. 230-258.

64. WEERAWARDENA J., MAVONDO F.T., 2011, Capabilities, Innovation and Competitive Advantage, in: Industrial Marketing Management, 40(8), p. 1220-1223.
65. WHRL R., HUSIG S., BOWLING M., 2009, The Interaction of R\&D Intensity and Firm Age: Empirical Evidence from Technology-based Growth Companies in the Germa 'Newer Market', in: Journal of High Technology Management Research, 20(1), p. 19-30.

66. YAM R.C.M., LO W., TANG E.P.Y., LAU A.K.W., 2011, Analysis of Sources of Innovation, Technological Innovation Capabilities, and Performance: An Empirical Study of Hong Kong Manufacturing Industries, in: Research Policy, 40(3), p. 391-402.

67. YAO L.G., DONG Z.L., 2010, Research on Core Competence of Corporation Based on Intellectual Capital, in: Advanced Materials Research,121-122, p. 237-242.

68. YU D., XIAO H., BO Q., 2018, The Dimensions of Organizational Character and Its Impacts on Organizational Performance in Chinese Context, in: Frontiers in Psychology, 9.

69. ZABALA I., PANADERO G., GALLARDO L.M. et al., 2005, Corporate Reputation in Professional Services Firms: Reputation Management Based on Intellectual Capital Management, in: Corporate Reputation Review, 8(1), p. 59-71. 
